\title{
Presence of Oxygen in Ti-Al-C MAX Phases-Based Materials and their Stability in Oxidizing Environment at Elevated Temperatures
}

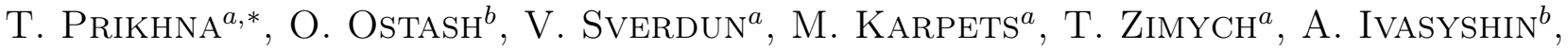 \\ T. Cabioc' ${ }^{c}$, P. Chartier ${ }^{c}$, S. Dub ${ }^{a}$, L. Javorska ${ }^{d}$, V. Podgurska ${ }^{b}$, P. Figel $^{d}$,

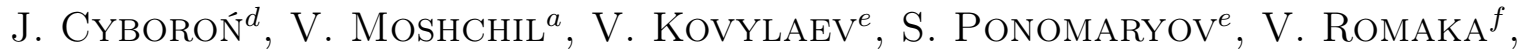 \\ T. SERBEnYUK ${ }^{a}$ And A. Starostina ${ }^{a}$ \\ ${ }^{a}$ Institute for Superhard Materials of the National Academy of Sciences of Ukraine, \\ 2 Avtozavodskaya Str., Kiev, 04074, Ukraine \\ ${ }^{b}$ Karpenko Physical-Mechanical Institute of the National Academy of Sciences of Ukraine, \\ 5, Naukova Str. Lviv, 79060, Ukraine \\ ${ }^{c}$ Université de Poitiers, CNRS/Laboratoire PHYMAT, UMR 6630 CNRS Université de Poitiers SP2MI, \\ BP 30179, F-86962 Chasseneuil Futuroscope Cedex, France \\ ${ }^{d}$ The Institute of Advanced Manufacturing Technology, Wroclawska 37A, 30-011 Krakow, Poland \\ ${ }^{e}$ EDL "Proton 21", 48a, Chernovola Str., Kiev's region 08132, Vishnevoe, Ukraine \\ ${ }^{f}$ Lviv Polytechnic National University, 12 Bandera Str., Lviv, 79013, Ukraine
}

The $\mathrm{Ti}_{3} \mathrm{AlC}_{2-},(\mathrm{Ti}, \mathrm{Nb})_{3} \mathrm{AlC}_{2^{-}}$and $\mathrm{Ti}_{2} \mathrm{AlC}$-based materials turned out to be more resistant than Crofer JDA steel in oxidizing atmosphere as $1000 \mathrm{~h}$ long tests at $600{ }^{\circ} \mathrm{C}$ have shown. But the amounts of oxygen absorbed by the materials during testing were different. The $\mathrm{Ti}_{2} \mathrm{AlC}$-based material demonstrated the lowest oxygen uptake, $(\mathrm{Ti}, \mathrm{Nb})_{3} \mathrm{AlC}_{2}$-based absorbed a somewhat higher amount and the highest amount was absorbed by $\mathrm{Ti}_{3} \mathrm{AlC}_{2}$-based material. Scanning electron microscopy and the Auger study witnessed that amounts of oxygen in the MAX phases before the exposure in air were as well different: the approximate stoichiometries of the matrix phases of materials were $\mathrm{Ti}_{3.1-3.2} \mathrm{AlC}_{2-2.2}, \mathrm{Ti}_{1.9-4} \mathrm{Nb}_{0.06-0.1} \mathrm{AlC}_{1.6-2.2} \mathrm{O}_{0.1-1.2}$ and $\mathrm{Ti}_{2.3-3.6} \mathrm{AlC}_{1-1.9} \mathrm{O}_{0.2-0.6}$, respectively. The higher amount of oxygen present in the MAX phase structures may be the reason for higher resistance to oxidation during long-term heating in air at elevated temperature. The studied materials demonstrated high stabilities in hydrogen atmosphere as well. The bending strength of the $\mathrm{Ti}_{3} \mathrm{AlC}_{2}$ - and $(\mathrm{Ti}, \mathrm{Nb})_{3} \mathrm{AlC}_{2}$-based materials after keeping at $600^{\circ} \mathrm{C}$ in air and hydrogen increased by $10-15 \%$, but the highest absolute value of bending strength before and after being kept in air and hydrogen demonstrated the $\mathrm{Ti}_{2} \mathrm{AlC}$-based material (about $590 \mathrm{MPa}$ ).

DOI: 10.12693/APhysPolA.133.789

PACS/topics: Ti-Al-C MAX phases, high- temperature resistance in air and hydrogen, hot pressing, bending strength

\section{Introduction}

The MAX-phases or nanolaminated ternary complex carbides and nitrides can be characterized by the general formula $\mathrm{M}_{n+1} \mathrm{AX}_{n}$, where $n=1$, 2 , or 3 ; $\mathrm{M}$ early transition metals (in our case $\mathrm{Ti}$ and $\mathrm{Nb}$ ); $\mathrm{A}$ - elements of A-group (in our case $\mathrm{Al}$ ), and $\mathrm{X}$ is $\mathrm{C}$ or $\mathrm{N}[1,2]$. They have perovskite-like crystal structures and the most abundant stoichiometries are $\mathrm{M}_{2} \mathrm{AX}(211), \mathrm{M}_{3} \mathrm{AX}_{2}$ (312) and $\mathrm{M}_{4} \mathrm{AX}_{3}$ (413), which in fact differ by the amount of carbide or nitride layers in the unit cells separated by layers of A-group metal elements. Materials have high bending and compression strength, fracture toughness at room and high temperatures (the destruction occurred mainly along the basal planes via kinks formation [3-6]),

*corresponding author; e-mail: prikhna@ukr.net excellent damping characteristics, high thermal shock resistance, chemical stability, good machinability. Besides, these materials are characterized by high electro- and thermal conductivities, low coefficients of friction and thermal expansion, resistance to radioactivity and oxidation. They also have self-healing properties [7-13]. Thus MAX-phase based materials are promising for application in different industries: power electrical, hydrogen, nuclear industries; aviation; space; mechanical and chemical engineering, etc. Recently $\mathrm{Ti}_{3} \mathrm{AlC}_{2}$-based materials have been proposed as interconnecting materials for hydrogen fuel cells, damping material for machining process and polishing powders for jewellery stones [12-14].

MAX-phases can form isostructural solid solutions by substituting in any sublattice that may cause the material properties improvement $[15,16]$. For example, reduction of thermal expansion coefficient anisotropy due to solid solution formation leads to the decrease of cracking during thermocycling, etc. 
Recently (Refs. [17-20]) the incorporation of oxygen in the $\mathrm{Ti}_{2} \mathrm{AlC}$ structure has been observed. The authors of [17] experimentally showed that oxygen can substitute carbon while the MAX phase structure was retained and they suggested the oxygen as a potential X element in parallel with carbon and nitrogen. Subsequent calculations [18] indicated that oxygen prefers the carbon site in the presence of oxygen at high temperature and that up to at least $50 \%$ of carbon may be replaced by oxygen [19]. Mockutè [20] has shown an oxygen content of 13 at.\% in $\mathrm{Ti}_{2} \mathrm{Al}(\mathrm{C}, \mathrm{O})$, with resultant composition of $\mathrm{Ti}_{2} \mathrm{Al}\left(\mathrm{C}_{0.48} \mathrm{O}_{0.52}\right)$. This corresponded to half of the carbon atoms substituted by oxygen, which turned out to be in the good agreement with a theoretically suggested oxygen solubility limit.

It is very difficult to synthesize single phased MAXphases-based materials. The intergrowth at nanolevel of $\mathrm{Ti}_{2} \mathrm{AlC}$ and $\mathrm{Ti}_{3} \mathrm{AlC}_{2}, \mathrm{Ti}_{2} \mathrm{AlC}$ and $\mathrm{TiC}, \mathrm{Ti}_{3} \mathrm{AlC}_{2}$ and $\mathrm{Al}_{3} \mathrm{Ti}$, etc. phases can be observed even in the so-called $\mathrm{X}$-ray single-phase materials [21]. The presence of oxygen and aluminum which can be added to the initial precursor powdered mixture may lead to the formation of dispersed $\mathrm{Al}_{2} \mathrm{O}_{3}$ inclusions in the MAX-phases matrix even if synthesis is performed in vacuum (due to high aluminium affinity to oxygen). Aluminum can evaporate during the manufacturing process, because MAX-phases melt incongruently. The narrow region existence of different MAX-phases [22] leads to the situation when during manufacturing processes (sintering or densification under pressure-temperature conditions) the equilibrium can be easily shifted from main MAX-phase toward the formation of MAX-phase of different structure type or toward other secondary phases, for example, TiC, intermetallics, etc.

The present paper is focused on the different oxidation resistance and stabilities in hydrogen atmosphere of the materials based on different MAX phases and which, as it turned out during the study, initially contained different amount of the admixture oxygen in their structures.

\section{Experimental}

The $\mathrm{Ti}_{2} \mathrm{AlC}$-, $\mathrm{Ti}_{3} \mathrm{AlC}_{2^{-}}$and $\left(\mathrm{Ti}_{1-x} \mathrm{Nb}_{x}\right) 3 \mathrm{AlC}_{2}$-based materials shaped as tablets $30-100 \mathrm{~mm}$ in diameter and 10-40 $\mathrm{mm}$ in thickness were prepared. For the preparation of 211 and 312 structural types MAX-phases of ( $\mathrm{Ti}, \mathrm{Nb})-\mathrm{Al}-\mathrm{C}$ systems the mixtures of $\mathrm{TiC}, \mathrm{TiH}_{2}, \mathrm{Al}$, and $\mathrm{Nb}$ powders were taken in $\mathrm{Ti}_{2} \mathrm{AlC}_{0.8}, \mathrm{Ti}_{3} \mathrm{Al}_{1.25} \mathrm{C}_{2}$, $\mathrm{Ti}_{2.94} \mathrm{Nb}_{0.06} \mathrm{Al}_{1.25} \mathrm{C}_{2}$ stoichiometries, mixed and milled in high-energy planetary activator for 3 min using steel balls and then pelletized. The excess of aluminum as compared to 312 or 211 stoichiometry was necessary to compensate its evaporation during the synthesis. Hydrogen liberated from $\mathrm{TiH}_{2}$ and evaporated during the synthesis process as well. Materials were synthesized at $1350-1400^{\circ} \mathrm{C}$ for $0.5-3 \mathrm{~h}$ in vacuum furnace using $1.6 \times 10^{-3} \mathrm{~Pa}$ vacuum or $0.1 \mathrm{MPa}$ argon atmosphere and then densified by hot pressing at $30 \mathrm{MPa}$ for $1 \mathrm{~h}$ at the same temperatures.
Besides, the $95 \%$ pure $\mathrm{T}_{2} \mathrm{AlC}$-based material (other $5 \mathrm{wt} \%$ of $\mathrm{TiC}$ ) was synthesized from $\mathrm{TiC}, \mathrm{TiH}_{2}, \mathrm{Al}$ mixture under $30 \mathrm{MPa}, 1400^{\circ} \mathrm{C}$, for $10 \mathrm{~min}$.

The materials compositions and structures were studied by the X-ray analysis with the Rietveld refinement and by JAMP-9500F (field emission Auger microprobe combined with scanning electron microscopy (SEM)). The JAMP-9500F is equipped by the argon ion etching gun that gives a possibility to remove an oxidized surface layer before the study directly in the vacuum chamber and to analyze quantitatively the composition of nanoinclusions. The depth of the analyzed by the Auger quantitative analysis layer is just two lattice parameters and the radius of analyzed area is about $10 \mathrm{~nm}$. X-ray diffraction (XRD) data were obtained on the polished face of the sample, diffractograms were taken in monochromatic $\mathrm{Cu} K_{\alpha}$ radiation and a single crystal of graphite mounted on a diffracted beam was used as a monochromator. The porosity and the true density of samples were measured using Archimedes' law.

For estimation of materials mechanical stability in hydrogen the bending tests using $2.5 \times 5 \times 40 \mathrm{~mm}^{3}$ samples under static loading according to three-point loading scheme were performed. The high purity hydrogen (99.99 vol.\%) under 0.15 MPa pressure was used. The bending strength $\sigma_{\text {bend }}$ was estimated as stress corresponding to the end of the diagram linear part. The strength in hydrogen was estimated at $600^{\circ} \mathrm{C}$ after holding for 3 and $40 \mathrm{~h}$ in comparison with its value in air at $20^{\circ} \mathrm{C}$ and $600{ }^{\circ} \mathrm{C}$.

The long-term oxidation resistances of materials in air at $600{ }^{\circ} \mathrm{C}$ were estimated by four-stages test on samples $5 \times 5 \times 8 \mathrm{~mm}^{3}$ in size which were previously weighed. At each stage samples were heated in electrical resistance furnace with a free access of air to the heating zone. After holding for $250 \mathrm{~h}$ the sample was cooled to room temperature, re-weighed and re-measured, then each sample was placed back into the furnace for the next test stage. The total test duration was $1000 \mathrm{~h}$. The oxidation resistance of the investigated material was evaluated by mass increment per unit of the sample surface area $\Delta m_{i} / S_{i}$ at each test stage ( $i$ is the number of test stage, $m_{i}$ is the weight and $S_{i}$ is the sample surface area for the $i$-th stage of the test; $\Delta m_{i}=m_{i}-m_{i-1}$. The test results of MAXphases and Crofer steel are presented as well for comparison. Today, one of the most common used material for interconnects in solid oxide fuel cells (SOFC) is chromite ferrite steels of the Crofer type containing $0.03 \%$ C, 20 $24 \% \mathrm{Cr}, 0.3-0.8 \% \mathrm{Mn}, 0.1-0.6 \% \mathrm{Si}$, up to $0.2 \% \mathrm{Ti}$, up to $0.2 \% \mathrm{La}$, up to $0.1 \% \mathrm{Al}$. These materials have high electrical and thermal conductivity, a satisfactory heat resistance and a coefficient of thermal expansion close to the electrolyte [23]. Their main disadvantage is the tendency to form volatile compounds $\mathrm{CrO}_{3}$ and $\mathrm{CrO}_{2}(\mathrm{OH})_{2}$, which predetermine "cathode pollution", and therefore, reduce the productivity of the SOFC. To prevent this and reduce the rate of oxidation, these alloys additionally alloy with manganese that forms over $\mathrm{Cr}_{2} \mathrm{O}_{3}$ oxide film spinel 
type $(\mathrm{MnCr})_{2} \mathrm{O}_{4}$, and also apply to the surface of the interconnect, which is in contact with the cathode and is in the oxidizing medium, conductive coatings. Another disadvantage of these materials, from the point of view of aerospace and automobile construction, is the high density, which causes a significant mass of the SOFC.

\section{Results and discussions}

Figure 1 demonstrates the X-ray patterns of the materials under study and their phase compositions estimated using the Rietveld refinement. The materials are not single-phased, but there are representatives of highly dense $\mathrm{Ti}_{3} \mathrm{AlC}_{2^{-}},(\mathrm{Ti}, \mathrm{Nb})_{3} \mathrm{AlC}_{2^{-}}$and $\mathrm{Ti}_{2} \mathrm{AlC}$-based MAX materials (numbered in this paper as $1-4$, respectively). Materials Nos. 3 and 4 have different amount of $\mathrm{Ti}_{2} \mathrm{AlC}$ phase.
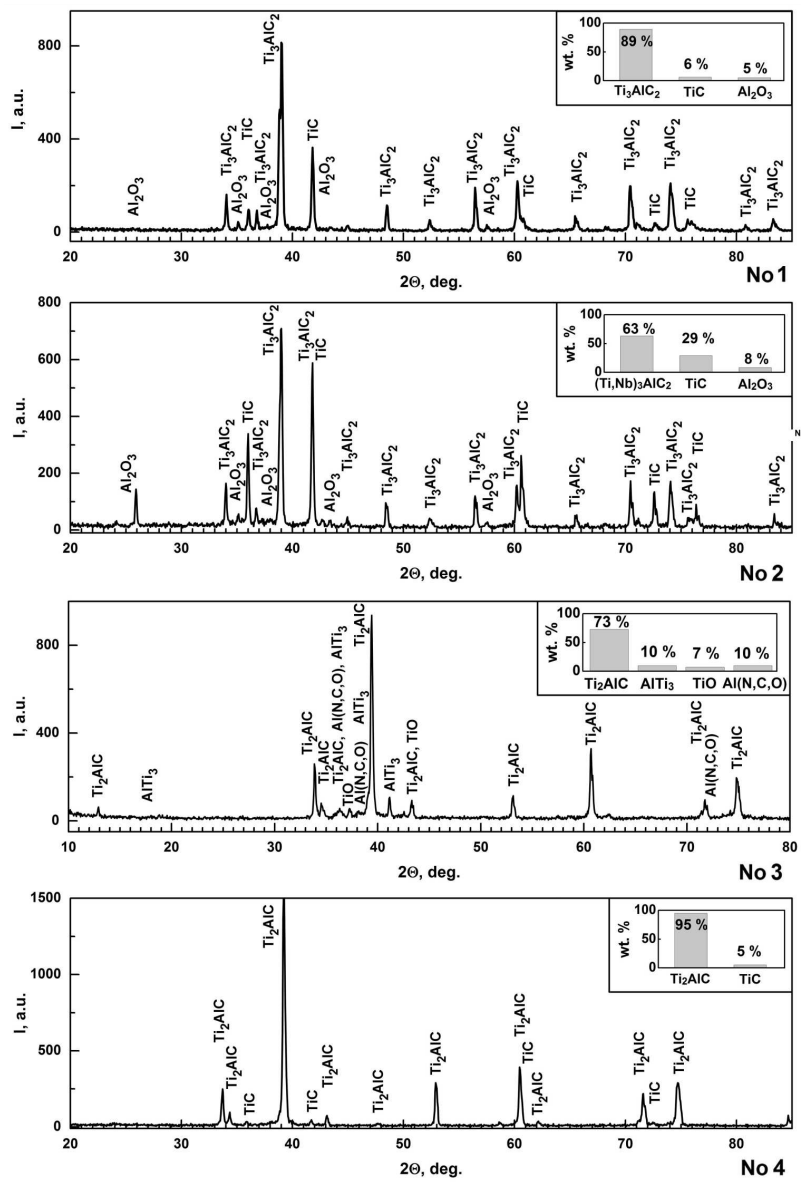

Fig. 1. The X-ray patterns and phase compositions (estimated using the Rietveld refinement) of the No. 1 $\mathrm{Ti}_{3} \mathrm{AlC}_{2-}$, No. $2(\mathrm{Ti}, \mathrm{Nb})_{3} \mathrm{AlC}_{2^{-}}$, and Nos. 3 and 4 $\mathrm{Ti}_{2} \mathrm{AlC}$-based MAX materials.

The materials structures are shown in Fig. 2 and the approximate phase compositions in Table I. They were studied using SEM and energy dispersive X-ray analysis (EDX) and, besides, the compositions of the $\mathrm{Ti}_{2} \mathrm{AlC}-$ based materials (Nos. 3, 4) were investigated by the
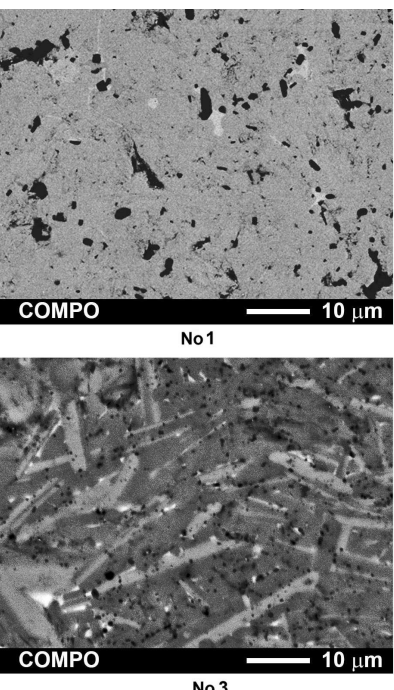

No 3

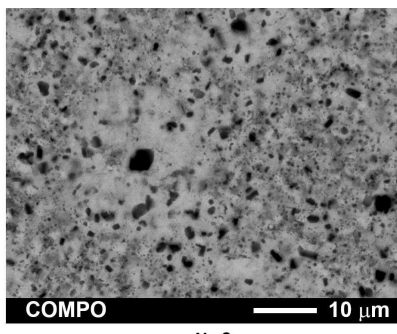

No2

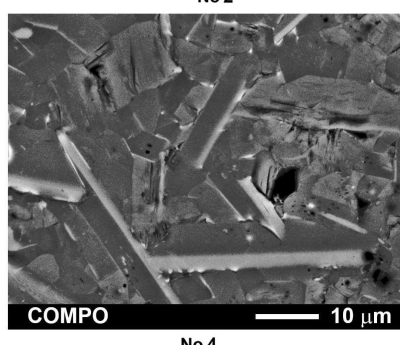

No 4

Fig. 2. Structure of the MAX-phases-based materials in COMPO (BEI - backscattering electrons) mode and the results of quantitative study by microprobe X-ray analysis. Samples 1-3 were synthesized in vacuum for $3 \mathrm{~h}$ at $1350{ }^{\circ} \mathrm{C}$ and then densified at $30 \mathrm{MPa}, 1350^{\circ} \mathrm{C}$ for $1 \mathrm{~h}$. Sample 4 was synthesized under $30 \mathrm{MPa}, 1350^{\circ} \mathrm{C}$ for $10 \mathrm{~min}$. The results of the quantitative study by microprobe X-ray analysis are given in Table I.
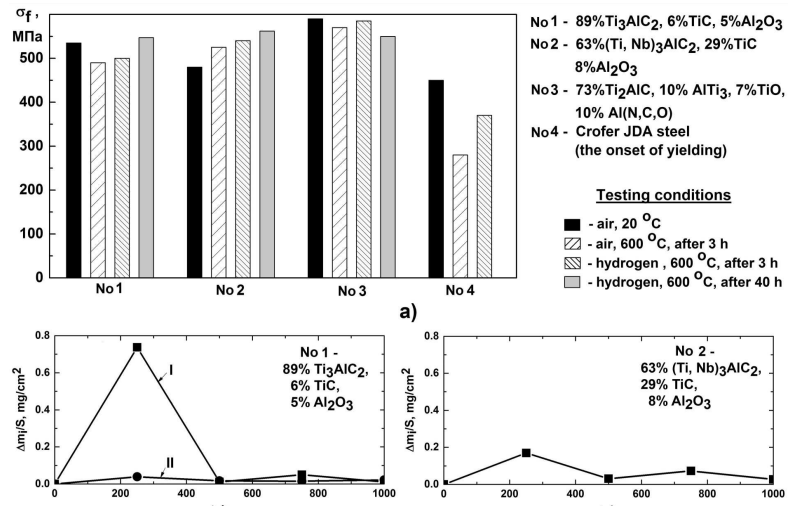

b)
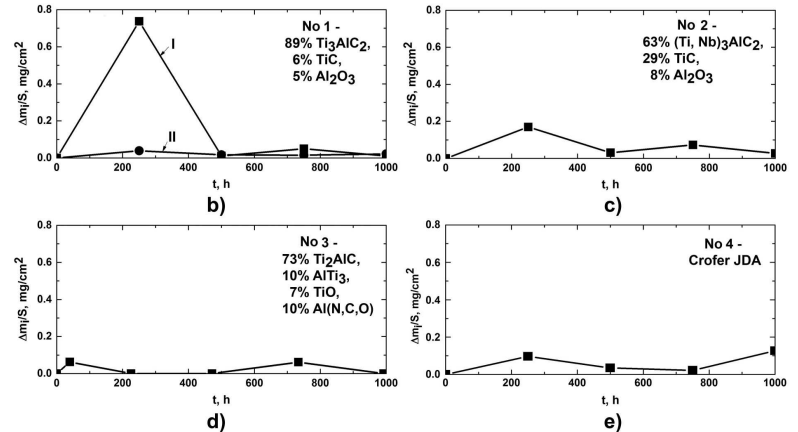

Fig. 3. The results of bending strength tests of the MAX phases-based materials Nos. 1-3 and Crofer JDA steel at room temperature and after heating for $3 \mathrm{~h}$ and $40 \mathrm{~h}$ at $600{ }^{\circ} \mathrm{C}$ in air and hydrogen (a) and long-term (up to $1000 \mathrm{~h}$ ) annealing in air at $600^{\circ} \mathrm{C}((\mathrm{b})-(\mathrm{e})$ ). In Fig. 2b curve I characterizes the behavior of $\mathrm{Ti}_{3} \mathrm{AlC}_{2}$ based material as it was manufactured (synthesized in vacuum and densified by hot pressing), while curve II characterizes the material behavior after additional annealing in air at $1200{ }^{\circ} \mathrm{C}$ for $2 \mathrm{~h}$. 
TABLE I

Phase compositions according to microprobe analysis of the structures in Fig. 2a-d. Numbers 1-4 in the table corresponds to parts a-d, respectively. AA - main matrix phase, BB - black inclusions, CC - light gray phase in the matrix or separate inclusions, DD - the brightest phase or inclusions.

\begin{tabular}{|c|c|c|}
\hline No. & $\mathrm{AA}$ & $\mathrm{BB}$ \\
\hline 1 & $\mathrm{Ti}_{3.2} \mathrm{AlC}_{2.1-2.2}$ & $\mathrm{Al}_{2} \mathrm{O}_{3.5-3.6}$ \\
\hline 2 & $\mathrm{Ti}_{1.9-4} \mathrm{Nb} .06-.1 \mathrm{AlC}_{1.6-2.2} \mathrm{O} .1-1.2$ & 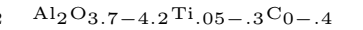 \\
\hline 3 & $\mathrm{Ti}_{2.2-2.4} \mathrm{AlC}_{1-1.1} \mathrm{O} .1-.3$ & $\mathrm{AlO}_{3.8-2.3 \mathrm{Ti}_{1.4-1.7} \mathrm{C} .3-.5}$ \\
\hline 4 & $\mathrm{Ti}_{2} \mathrm{Al}_{.9} \mathrm{C}_{.9} \mathrm{O} .16$ & $\mathrm{Ti}_{2} \mathrm{Al}_{1.4-1.96} \mathrm{C} .37-.47 \mathrm{O}_{5.1-7.4}$ \\
\hline No. & $\mathrm{CC}$ & DD \\
\hline 1 & - & - \\
\hline 2 & $\mathrm{TiC}_{.8-.9} \mathrm{Al} .1-.{ }^{\mathrm{Nb}} .02-.03 \mathrm{O} .6-.7$ & $\mathrm{Ti}_{3-3.4} \mathrm{Nb} .{ }_{1} \mathrm{AlC}_{2.2-2.3}$ \\
\hline 3 & $\mathrm{Ti}_{3.2-4.2} \mathrm{AlC}_{1.7-2} \mathrm{O} .4-.9$ & $\mathrm{Ti}_{2} \mathrm{Al}_{.7} \mathrm{C}_{1.1} \mathrm{O}_{1.5}$ \\
\hline 4 & $\mathrm{Ti}_{2} \mathrm{Al} .39-.83^{\mathrm{C}} .75-1.26$ & $\mathrm{Ti}_{2} \mathrm{Al}_{1.1} \mathrm{C} .5 \mathrm{Fe} .3$ \\
\hline
\end{tabular}

Auger spectroscopy. The surfaces of the all studied samples were achieved by Ar ions in the chamber of microscope in order to remove the oxidized surface layers before performing the microprobe or Auger analysis. All materials demonstrate rather complicated structures and compositions. In the case of $\mathrm{T}_{3} \mathrm{AlC}_{2}$-based material (No. 1) its matrix phase was practically oxygen-free and the admixture oxygen formed separate inclusions (appeared black in the image) with near $\mathrm{Al}_{2} \mathrm{O}_{3}$ stoichiometry. In the case of $\mathrm{Nb}$ addition (No. 2) some oxygen was present in the material matrix and black inclusions contained small amount of $\mathrm{Ti}$ and $\mathrm{C}$ in addition to $\mathrm{Al}$ and $\mathrm{O}$. The structures of $\mathrm{Ti}_{2}$ AlC-based materials (Nos. 3 and 4 ) turned out to be more complicated. In the material No. 3 (contained according to the $\mathrm{X}$-ray phase analysis smaller (73 wt\%) amount of $\mathrm{Ti}_{2} \mathrm{AlC}$ phase) rather high quantity of oxygen was found practically in all phases and the appeared black phase contained much higher amount of $\mathrm{Ti}$ and $\mathrm{C}$ in addition to $\mathrm{Al}$ and $\mathrm{O}$ then that of the material No. 2. The presence of high amount of oxygen has been confirmed by the Auger study. The amount of oxygen in the matrix phase of material No. 3 was higher than that in the matrix of material No. 2. The highest amount (95 wt\%) of the phase with $\mathrm{Ti}_{2} \mathrm{AlC}$ structure was revealed in the material No. 4 . The results of microprobe and the Auger study showed the presence of oxygen in its matrix phase as well. Black areas (or inclusions) in material No. 4 contained very high amount of oxygen while the concentration of carbon was lower and the concentration of aluminum was somewhat higher than those in the material matrix.

Figure 3 shows the results of bending strength tests and long-term for $1000 \mathrm{~h}$ oxygenation of the materials Nos. $1-3$ by heating in air at $600^{\circ} \mathrm{C}$. In the case of Crofer JDA steel for comparison we took the values of the beginning of yielding because the steel has much higher plasticity than any of the MAX phases [13]. All the materials under study (Fig. 3a) demonstrated high stability in air and hydrogen atmosphere at elevated temperature $\left(600^{\circ} \mathrm{C}\right.$, i.e. at possible working temperature of hydrogen fuel cell). It has been observed even some increase of bending strength after the treatment in air for $3 \mathrm{~h}$ at $600^{\circ} \mathrm{C}$ for No. $2(\mathrm{Ti}, \mathrm{Nb})_{3} \mathrm{AlC}_{2}$-based material (Fig. 3a). We assign the observed effect to self-healing process. The bending strength of both No. $1 \mathrm{Ti}_{3} \mathrm{AlC}_{2}$ and No. $2(\mathrm{Ti}, \mathrm{Nb})_{3} \mathrm{AlC}_{2}$-based materials after being kept in hydrogen for $40 \mathrm{~h}$ increased by $10-15 \%$. The highest absolute values of bending strength in air and in hydrogen showed by material No. 3 .

The long-term heating in oxidizing atmosphere (Figs. 3b-e) demonstrated that the MAX phases-based materials are more stable than Crofer steel: after $1000 \mathrm{~h}$ of heating the decomposition of steel has been observed, while MAX phases-based materials were stable. The stability of the MAX phases increased with the increase of the oxygen content in their structures, please, see Table in Fig. 2 and Table I. The preliminary heating in air at $1200^{\circ} \mathrm{C}$ for $2 \mathrm{~h}$ of No. $1 \mathrm{Ti}_{3} \mathrm{AlC}_{2}$-based material essentially improved its stability in air or in oxidizing atmosphere at $600^{\circ} \mathrm{C}$ (please compare curves I and II in Fig. 3b). The most stable among the studied Nos. 13 turned out to be No. $3 \mathrm{Ti}_{2}$ AlC-based MAX material, which contained the highest amount of oxygen. The theoretical density of $\mathrm{Ti}_{2} \mathrm{AlC}$ is $4.11 \mathrm{~g} / \mathrm{cm}^{3}$ and the density of No. 3 with $73 \mathrm{wt} \%$ of $\mathrm{Ti}_{2} \mathrm{AlC}$ was $4.04 \mathrm{~g} / \mathrm{cm}^{3}$ which is about twice lower than that of Crofer JDA steel.

The study of No. $1 \mathrm{Ti}_{3} \mathrm{AlC}_{2^{-}}$, and No. $2(\mathrm{Ti}, \mathrm{Nb})_{3} \mathrm{AlC}_{2^{-}}$ based materials after long-term heating in air by SEM demonstrated that the thickness of an oxide film on the surface of No. 1 was about $100 \mu \mathrm{m}$ while that of No. 2 was less than $10 \mu \mathrm{m}$ and that $\mathrm{Nb}$ was present in all phases and in the surface oxidized layer as well.

\section{Conclusions}

The 211 and 312 MAX-phases-based materials of $\mathrm{Ti}, \mathrm{Nb}-\mathrm{Al}-\mathrm{C}$ system are stable in hydrogen and oxidizing environments at elevated temperatures $\left(600^{\circ} \mathrm{C}\right)$ and are even more stable than Crofer (Crcontaining) steels. Besides, MAX-phases are about twice lighter. The most resistant in oxidizing atmosphere at $600{ }^{\circ} \mathrm{C}$ for $1000 \mathrm{~h}$ among the studied materials turned out to be the material containing $73 \mathrm{wt} \%$ of $\mathrm{Ti}_{2} \mathrm{AlC}$ phase (according to the X-ray analysis). This material consisted of oxygen-containing phases $\mathrm{Ti}_{2.2-2.4} \mathrm{AlC}_{1-1.1} \mathrm{O}_{0.1-0.3}$ (matrix) and $\mathrm{Ti}_{3.2-4.2} \mathrm{AlC}_{1.7-2} \mathrm{O}_{0.4-0.9}, \quad \mathrm{AlO}_{3.8-2.3} \mathrm{Ti}_{1.4-1.7} \mathrm{C}_{0.3-0.5}$, $\mathrm{Ti}_{2} \mathrm{Al}_{0.7} \mathrm{C}_{1.1} \mathrm{O}_{1.5}$ according to the SEM study. The Auger study confirmed the presence of oxygen in $\mathrm{Ti}_{2} \mathrm{AlC}$-based materials.

The added $\mathrm{Nb}$ (in small amount to the initial mixture) after synthesis was found practically in all phases present in the material after synthesis and in the oxidized surface layer (formed during long-term oxidation) as well. The addition of $\mathrm{Nb}$ increases the 312-MAX phase-based material stability in oxide environment and leads to the formation of about 10 times thinner Nb-containing oxidized layer on the material surface as compared to that without the addition, possibly, due to the fact that in the materials with $\mathrm{Nb}$ addition some oxygen was present. The higher concentration of oxygen was observed in the material, the higher was its stability in oxidizing environment. 
All the studied MAX phases-based materials were stable in hydrogen and for $\mathrm{Ti}_{3} \mathrm{AlC}_{2}$, and $(\mathrm{Ti}, \mathrm{Nb})_{3} \mathrm{AlC}_{2}$-based even the increase of bending strength after treatment at $600^{\circ} \mathrm{C}$ in hydrogen has been observed. The characteristics of the developed materials make them promising for application, for example, as interconnect materials for hydrogen fuel cells.

\section{References}

[1] M. Barsoum, Prog. Solid State Chem. 28, 201 (2000).

[2] M. Barsoum, D. Brodkin, T. El-Raghy, Scr. Met. Mater. 36, 535 (1997).

[3] T. El-Raghy, A. Zavaliangos, M. Barsoum, S. Kalidindi, J. Am. Ceram. Soc. 80, 513 (1997).

[4] B. Kooi, R. Poppen, N. Carvalho, J. de Hosson, M. Barsoum, Acta Mater. 51, 2859 (2003).

[5] J. Molina-Aldareguia, J. Emmerlich, J.-P. Palmquist, U. Jansson, L. Hultman,Scr. Mater. 49, 155 (2003).

[6] T. Prikhna, S. Dub, A. Starostina, M. Karpets, T. Cabiosh, P. Chartier, J. Superhard Mater. 34, 102 (2012).

[7] X. Wang, Y. Zhou, J. Mater. Sci. Technol. 26, 385 (2010).

[8] Z. Sun, Int. Mater. Rev. 56, 143 (2011).

[9] K. Whittle, M. Blackford, R. Aughterson, S. Moricca, G.R. Lumpkin, D.P. Riley, N.J. Zaluzec, Acta Mater. 58, 4362 (2010).

[10] X. Wang, Y. Zhou, Corros. Sci. 45, 891 (2003).

[11] G. Song, W. Sloof, S. Li, S. Van der Zwaag, in: Proc. First Int. Conf. on Self Healing Materials, Eds.: S. van der Zwaag, E. Brinkman,, Noordwijk aan Zee, The Netherlands 2007, p. 96.
[12] T. Prikhna, T. Cabiosh, W. Gawalek, O. Ostash, D. Lizkendorf, S. Dub, M. Loshak, V. Sverdun, P. Chartier, T. Basyuk, V. Moshchil, A. Kozyrev, M. Karpets, V. Kovylaev, A. Starostina, D. Turkevich, Adv. Sci. Technol. 89, 123 (2014).

[13] T. Prikhna, O. Ostash, T. Basyuk, A. Ivasyshyn, V. Sverdun, M. Loshak, S. Dub, V. Podgurska, V. Moshchil, T. Cabioc'h, P. Chartier, M. Karpets, V. Kovylaev, O. Starostina, A. Kozyrev, Solid State Phenom. 230, 140 (2015).

[14] T. Prikhna, A. Starostina, I. Petrusha, S. Ivakhnenko, A. Borimskii, Yu. Filatov, M. Loshak, M. Serga, V. Tkach, V. Turkevich, V. Sverdun, S. Klimenko, D. Turkevich, S. Dub, T. Basyuk, M. Karpets, V. Moshchil', A. Kozyrev, G. Il'nitskaya, V. Kovylyaev, D. Lizkendorf, T. Cabiosh, P. Chartier, J. Superhard Mater. 36, 9 (2014).

[15] T. Cabioch, P. Eklund, V. Mauchamp, M. Jaouen, M. Barsoum, J. Europ. Ceram. Soc. 33, 397 (2013).

[16] T. Cabioc'h, P. Eklund, V. Mauchamp, M. Jaouen, J. Europ. Ceram. Soc. 32, 1803 (2012).

[17] J. Rosen, P.O.Å. Persson, M. Ionescu, A. Kondyurin, D.R. McKenzie, M.M.M. Bilek, Appl. Phys. Lett. 92, 064102 (2008).

[18] T. Liao, J. Wang, M. Li, Y. Zhou, J. Mater. Res. 24 3190 (2009).

[19] M. Dahlqvist, J. Rosen, Defect formation and oxygen incorporation in $\mathrm{Ti}_{2} \mathrm{AlC}, \mathrm{V}_{2} \mathrm{AlC}$, and $\mathrm{Cr}_{2} \mathrm{AlC}$ from first principles calculations, in manuscript.

[20] A. Mockutè, Synthesis and Characterization of New MAX Phase Alloys, LiU-Tryck, Linköping 2014.

[21] X. Wang, Y. Zhou, Acta Mater. 50, 3141 , (2002).

[22] A. Zhou, C. Wang, Y. Huang, Mater. Sci. Eng. A 352, 333 (2003).

[23] S. Fontana, R. Amendola, S. Chevalier, J. Power Sources 171, 652 (2007). 